\title{
KRT10 Gene
}

National Cancer Institute

\section{Source}

National Cancer Institute. KRT10 Gene. NCI Thesaurus. Code C112151.

This gene plays a role in intermediate filament structure. 